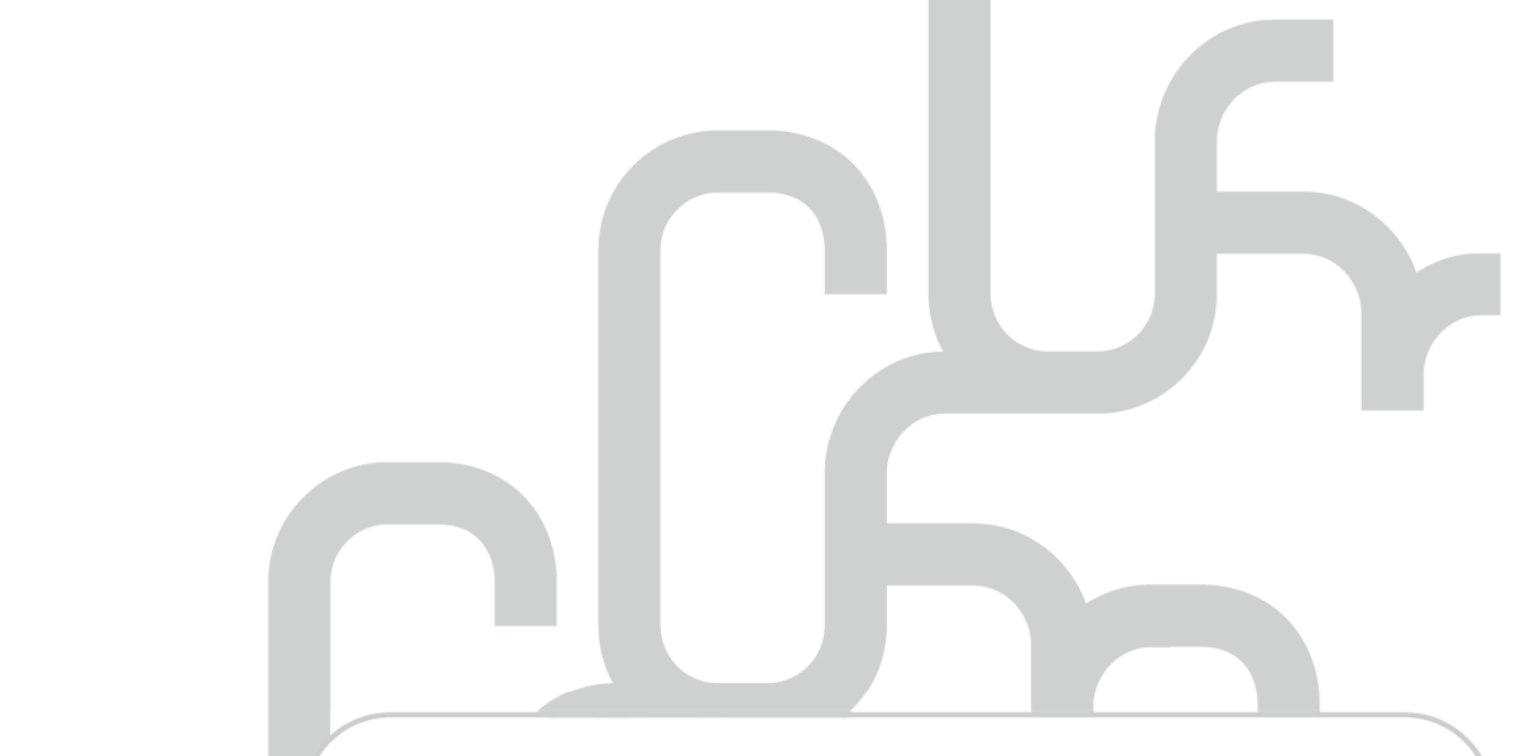

CfR-working Paper No. 05-08

mutual fund orowth in standard and specialist market segments

s. Ruenzi

centre for financial Research Look deeper 


\title{
MUTUAL FUND GROWTH IN STANDARD AND SPECIALIST MARKET SEGMENTS
}

\author{
Stefan Ruenzi* \\ Department of Finance \\ University of Cologne \\ and \\ Centre for Financial Research (CFR) Cologne \\ Albertus-Magnus-Platz \\ 50923 Koeln \\ Germany
}

April 2005

* e-mail: ruenzi@wiso.uni-koeln.de. Tel. ++40-(0)221-4706966. The author wishes to thank Vikas Agarwal, Silke Ber, Alexander Kempf, Youchang Wu and two anonymous referees for their insightful comments and suggestions and Alexandra Niessen for valuable research assistance while retaining responsibility for all remaining errors. An earlier version of this paper has been presented at the Cologne Graduate School of Risk Management in 2004 and at the $8^{\text {th }}$ meeting of the Swiss Society for Financial Market Research in Zürich in 2005. 


\title{
MUTUAL FUND GROWTH IN STANDARD AND SPECIALIST MARKET SEGMENTS
}

\begin{abstract}
This paper is concerned with differences in the performance-flow relationship (PFR) between standard and specialist market segments of the mutual fund industry. We expect differences in this relationship because investor characteristics might vary across different segments. Our results show that the PFR is more convex in standard segments as compared to specialist segments. Furthermore, investors in standard segments are less risk-averse and invest more in high-load funds than investors in specialist segments. Our findings are consistent with investors in standard segments being less sophisticated than investors in specialist segments and to rely more heavily on the advice of financial brokers, which is compensated for by load fees.
\end{abstract}




\section{Introduction}

Mutual funds are offered in a wide variety of market segments. This paper is concerned with determinants of mutual funds' growth in these different segments. Specifically, we examine the relationship between a mutual fund's performance and its subsequent growth due to net-inflows. The contribution of our paper is to investigate differences of this performance flow relationship (PFR) across different segments of the industry. Such differences with respect to the PFR and with respect to other determinants of fund inflows like past return risk and fees have not been systematically examined in the literature so far.

Although there are several papers that examine the PFR [see, e.g., IPPOLITO (1992), CHEVALIER/ELLISON (1997), and SIRRI/TUFANO (1998)], all of them look at the large standard segments of the mutual fund industry like Growth or Growth \& Income or at more specialized segments only in isolation. They report that the PFR is positive and convex.

There is evidence that investor characteristics as well as search costs to find a specific fund influence the convexity of the PFR [see, e.g., SIRRI/TUFANO (1998), DELGUERCIO/TKAC (2002), and HUANG/WEI/YAN (2004)]. We argue that investor characteristics and search costs vary across segments. Therefore, these differences should be reflected in differences in the convexity of the PFR.

Our empirical study covers the whole US equity mutual fund market for the time period 1993 to 2001. Our main result is that the PFR in large segments (which we label as 'standard') is significantly more convex than the PFR in the usually more exotic small segments (which we label as 'specialist').

Furthermore, our study provides two interesting additional insights: first, the average investor in standard segments tends to invest in high load fee funds, whereas the average investor in small segments is averse to fees. Second, investors' reaction to risk differs between large and small segments. Our results indicate that investors in large segments seem to prefer high-risk funds whereas investors in small segments do not.

The option-like characteristics of a convex PFR gives rise to risk-taking incentives for the managers of individual funds, because they get paid dependent on their assets under management [KHORANA (1996)].[1] BROWN/HARLOW/STARKS (1996), CHEVALIER/ELLISON (1997), ELTON/GRUBER/BLAKE (2000) and KEMPF/RUENZI (2004a) all present empirical evidence that fund managers strongly react to these incentives. According to option theory the strength of these incentives positively depends on the strength of the convexity of the PFR. CHEVALIER/ELLISON (1997) confirm this theoretical prediction by showing empirically that fund managers react stronger to these incentives the more convex the PFR is. Our main result of a more convex PFR in standard segments leads to, ceteris paribus, stronger risk taking incentives for fund managers. These incentives are even reinforced by the fact that fund growth in standard segments positively depends on past return risk.

The schedule of this paper is as follows: Section 2 describes how search costs and investors' characteristics influence the PFR. Furthermore, we explain how these characteristics vary between different segments and what consequences this has for the PFR. In Section 3, we present 
the empirical model and describe the data. The differences in the PFR are examined in Section 4, where we also conduct several robustness checks. Section 5 concludes and provides possible directions for future research.

\section{Search Costs, Investor Characteristics, and the PFR}

The PFR has two main characteristics. The first characteristic is that it is positive. A positive PFR can be rationalized by the fact that there is some - albeit only weak - evidence for persistence in mutual fund performance [see, e.g., BROWN/GOETZMANN (1995), ELTON/GRUBER/BLAKE (1996), and BOLLEN/BUSSE (2001)]. Therefore, it is a sensible strategy for fund investors to base their purchase decisions on past performance.

The second striking characteristic of the PFR is its pronounced convexity [see, e.g., IPPOLITO (1992), SIRRI/TUFANO (1998), CHEVALIER/ELLISON (1997), and KEMPF/RUENZI (2004b)]. The extreme growth of top-funds and the lack of outflows from badly performing funds are harder to explain in the context of a rational model. Why should an investor stick with a bad fund? An argument can be made, that investors who picked a bad fund in the past have learned that they are not very good at picking funds. However, even if these investor might not be able to pick a star fund, they are still better off switching to any other fund if transaction costs are not too high.[2] Therefore, the strong reluctance to sell losers still presents a puzzle, given that strong persistence is mainly documented for badly performing funds [see, e.g., BROWN/GOETZMANN (1995)]. Overall, investors seem to have problems to correctly assess future performance prospects of funds.

There are two possible explanations for a convex PFR. First, fund investors base their purchase decisions on past performance, but later do not sell funds that show a bad performance [see, e.g., GOETZMANN/PELES (1997)]. This averseness to sell losers can be explained by investors being subject to a disposition effect [SHEFRIN/STATMAN (1985)]. Second, top-performing funds are more visible than bad or mediocre funds for several reasons. For example, the financial press often reports about star performers. Furthermore, such top-funds also show up high in the performance rankings. Finally, fund families place ads for their best funds [JAIN/WU (2000)]. Therefore, even uninformed investors will be familiar with these top-funds. They are consequently more likely to be bought. This leads to the observed disproportional high inflows into top-performing funds. The combination of investors being subject to a disposition effect and their familiarity with past top performers can explain the observed convex PFR.

The strength of the disposition effect as well as the visibility of funds are likely to differ between different market segments for at least three possible reasons:

- First, the share of first-time investors is likely to vary across segments. We argue that such rather inexperienced investors are more likely to be prone to behavioral biases like the disposition effect.[3] It is reasonable to assume, that these investors usually turn to one of the well-known funds from the large standard segments first.

- Second, the share of wealthy investors is also likely to vary across segments. Wealthy fund investors hold a portfolio of funds from different standard and specialist segments, 
while less wealthy investors will be forced to concentrate on a small number of funds due to cost considerations. Therefore, the latter will usually concentrate on some large, welldiversified funds from the large standard segments, in order to still achieve a sufficiently diversified portfolio. This leads us to suppose that the share of wealthy investors is higher in specialist segments than in standard segments. As these wealthy investors are usually more experienced, they should also be less prone to behavioral biases.

- Third, fund families mainly advertise their large flagship funds, which usually belong to one of the large standard segments [JAIN/WU (2000)]. Furthermore, the popular press mainly focuses on standard segments and the performance rankings for these segments are most widely observed. Therefore, top-funds from these segments are more visible to investors than funds from other segments.

Because of all of these reasons, we would expect a more pronounced convexity of the PFR in standard segments than in smaller and often more exotic specialist segments. The results we present below support this view.

\section{Methodology and Data Source}

\subsection{Empirical Model}

We use pooled OLS regressions to examine the relationship between a fund's growth and its previous performance as well as other variables that might influence fund growth.[4] Our dependent variable is the growth, $\mathrm{g}_{\mathrm{i}, \mathrm{t}}$, of fund $\mathrm{i}$ in year $\mathrm{t}$ due to new inflows. As there are no data on net inflows available in our database, we follow the literature [e.g. SIRRI/TUFANO (1998)] and compute $g_{i, t}$ by subtracting the rate of return earned on the assets under management from the growth rate of the total net assets (TNA) the fund has under management.

PATEL/ZECKHAUSER/HENDRICKS (1994) show that ordinal performance measures based on raw returns are able to explain fund growth better than cardinal measures. They also show that ranks based on returns can explain fund growth better than ranks based on risk-adjusted performance measures. Therefore, we use segment ranks based on returns as independent variables in our regressions. Rank $k_{i, t}$ denotes the relative return rank of fund $i$ in year $t$ within its market segment. Rank numbers are evenly distributed between 0 and 1 . The best fund gets assigned the rank number 1 . As a stability test, we will later use ranks based on various riskadjusted performance measures. Our main results do not hinge on the choice of the performance measure (see Section 4.4).

Note, that the ranking system we use ensures that funds from segments with different numbers of funds can be easily compared. However, this ranking system might also give rise to another phenomenon: Assume that the rankings in the popular press always show the, e.g., Top-10 funds in a segment. According to our ranking system, the $10^{\text {th }}$ best fund in a large segment will be ranked lower than the $10^{\text {th }}$ best fund in a smaller segment, although both funds would have the same visibility to potential investors due to their appearance in the Top-10 listing. To control for such potential effects, in regressions not reported we include a dummy variable that takes on the value one, if a fund belongs to the Top-10, Top-5 and Top-3 in its segment, respectively, and 
zero otherwise. The results we report below are not affected, if we include such an additional dummy.[5]

To account for the supposed non-linearity of the PFR we apply the specification suggested in BARBER/ODEAN/ZHENG (2004). They use the segment rank, Rank $k_{i, t-1}$, and the squared segment rank, Rank ${ }_{i, t-1}^{2}$, as independent variables.[6] A positive influence of the squared segment rank indicates a convex PFR. We will also apply a piecewise-linear regression approach as suggested by SIRRI/TUFANO (1998) (see Section 4.4).

To examine possible differences between the convexity of the PFR in standard and specialist segments, we add interaction-terms between a dummy variable $\mathrm{D}$ and the performance variables $\operatorname{Rank}_{\mathrm{i}, \mathrm{t}-1}$ and $\operatorname{Rank}_{\mathrm{i}, \mathrm{t}-1}^{2}$. D takes on the value one, if a fund belongs to the standard segments, and zero otherwise. The significance of the dummy-interacted terms indicates the significance of the difference in the influence of the respective independent variable between standard and specialist segments. A positive estimate for the influence of $\operatorname{Rank}_{\mathrm{i}, \mathrm{t}-1}^{2} \mathrm{D}$ is evidence for a stronger convexity of the PFR in the standard segments than in the rest of the market. It captures the additional convexity in standard segments. Our regression model reads:

$$
g_{i, t}=\beta_{1} \operatorname{Rank}_{i, t-1}+\beta_{2} \operatorname{Rank}_{i, t-1}^{2}+\beta_{1 L} \operatorname{Rank}_{i, t-1} D+\beta_{2 L} \operatorname{Rank}_{i, t-1}^{2} D+\gamma \text { Controls }+\sum_{j=1993}^{2001} \alpha_{j} D_{j}+\varepsilon_{i, t}
$$

Controls denotes a vector of control variables. They are described in Table 1. These variables are examined as potential determinants of fund growth in previous studies. We include all variables whose realizations are not known to investors at the beginning of the year with their previous year realization and follow the literature by using the natural logarithm of age and size [see, e.g., BARBER/ODEAN/ZHENG (2004)].

\section{Please Insert Table 1}

As we examine funds from different segments, we also include the growth of the segment the fund belongs to as control variable. Thereby, we control for other factors that drive the growth of all funds in a specific segment. For example, it is possible that a specific segment becomes fashionable and the funds in this segment experience large growth rates. We allow for a nonlinear influence of the growth of the segment a fund belongs to by adding the squared growth rate of the segment in addition to the growth rate of the segment itself.

As we use observations from all years in one pooled regression, we have to control for yearspecific influences on fund growth. Therefore, we add a dummy, $\mathrm{D}_{\mathrm{j}}$, for each year of our sample. Each yearly dummy takes on the value 1, if the observation is from the respective year, and zero otherwise. We will not report estimation results for the influence of the yearly dummies for the sake of brevity. As we use one dummy variable for each year, we do not add a constant term in our regressions, as this would make the regressors linearly dependent.

\subsection{Data}


We use data on all US equity mutual funds from the CRSP Survivorship Bias Free Mutual Fund Database.[7] This database contains all necessary information to conduct our study. Specifically, the database lists the Strategic Insight (SI) objective classification for each fund. This classification defines the market segments. As the SI-objectives are available from 1993 on, our study starts in this year. It covers the years until 2001. We exclude all fund year observations with extreme growth rates of more than $500 \%$ as these are usually due to a very small asset base of the fund at the beginning of the year and as data in these cases often seems questionable.[8] We also exclude all fund year observations for which not all information used in our regressions is available. Some funds offer different share classes. As these classes differ substantially with respect to their fee structure and other characteristics, they are separate investment alternatives from the point of view of the fund investors. Therefore, we include all share classes of the funds as individual observations. Our main results do not hinge on this. They also hold, if we aggregate all share classes of a fund (see Section 4.3). However, looking at share classes individually allows us to examine the influence of the fee structure on fund growth in detail. Overall, our final sample consists of 15.172 fund year observations.

We classify the SI market segments contained in the database as either 'specialist' or 'standard' segments. We define the five largest segments according to the number of funds offered as 'standard', and the rest as 'specialist'. Our classification allows us to examine systematic differences between these two groups of segments. Standard segments are the SI-objective segments 'Growth', 'Growth \& Income', 'Small Company Growth', 'Balanced' and 'International Growth'. The specialist segments include segments like 'Chinese Equity Funds' or 'Health Sector Funds'. This split-up leads to 8,577 observations from standard segments and 6,595 observations from specialist segments. Although the cutoff for standard segments is somewhat ad-hoc, we chose this way of classifying segments, as any other methodology would have to rely on a subjective classification of the individual segments. We also examine our models defining the three and six largest segments, respectively, as standard segments. Our results (not reported here) are not affected. 


\section{Results}

\subsection{The PFR in the Whole Sample}

We start by estimating the PFR from model (1), but leave aside the dummy-interaction terms for the moment. This allows us to examine the convexity of the PFR in the whole market, without distinguishing between standard and specialist segments, and to compare our results to the literature. Results for the whole sample period 1993-2001 are presented in Column (A) of Table 2 .

\section{Please Insert Table 2}

We find strong evidence of a convex PFR. The coefficient for the influence of the squared segment rank is significantly positive. This result confirms the results reported in the literature [see, e.g., CHEVALIER/ELLISON (1997), and SIRRI/TUFANO (1998)].

With respect to the control variables, we find no significant influence of $\mathrm{std}_{\mathrm{i}, \mathrm{t}-1}$. This result suggests that the average mutual fund investor does not care about risk very much.[9] This surprising result is consistent with the results of earlier studies like SIRRI/TUFANO (1998), who also find no significant influence of past return standard deviation on money inflows. The fund's age, size and fees all have a significantly negative influence on fund growth. Funds with a higher turnover rate in the previous year tend to grow faster. The influence of the fund's previous year growth is significantly positive. Furthermore, the growth of a fund depends on the growth of the segment a fund belongs to in a concave manner. Overall, the estimates for the control variables confirm the findings of earlier studies. The $\mathrm{R}^{2}$ is over $18 \%$, which is similar to the $\mathrm{R}^{2}$ s reported in the literature. For example, SIRRI/TUFANO (1998) report a $\mathrm{R}^{2}$ of about $14 \%$. The $\mathrm{R}^{2}$ of a similar regression in ELTON/GRUBER/BLAKE (2000) is $17.9 \%$.

\subsection{Differences in the Convexity of the PFR}

We now turn to the examination of differences in the convexity of the PFR between standard and specialist segments. Results of our estimation of the complete model (1) are presented in Column (B) of Table 2. They indicate that the PFR in specialist as well as standard segments is clearly convex. More importantly, we find strong evidence for a difference in the convexity of the PFR. There is a positive and highly significant influence of $\operatorname{Rank}_{\mathrm{i}, \mathrm{t}-1} \mathrm{D}$ on fund growth. This coefficient denotes the additional convexity, which is due to the fact that a fund belongs to a standard segment rather than to a specialist segment. This result strongly supports our main hypothesis that the convexity of the PFR is more pronounced in standard segments than in specialist segments. As a robustness check, in Column (C) we report results of an estimation of model (1), where we aggregate all share classes of a fund. Results are very similar. In the following we will treat each share class as single observation again, as this allows us to take a closer look at the influence of the fee structure on fund growth (see Section 4.3).

As risk-taking incentives for fund managers positively depend on the convexity of the PFR, our results suggest stronger risk-taking incentives for fund managers in standard than in specialist segments. However, these stronger incentives might be neutralized. For example, it is possible 
that popular funds from the standard segments are more closely followed by the press and rating agencies. If they report negatively about the excessive risk-taking of these funds, this might have a negative impact on their growth. Furthermore, it is possible that fund investors in standard segments are more risk-averse than investors in specialist segments. We turn to a detailed examination of the influence of risk in the following section.

\subsection{Differences in the Influence of Risk and Fees}

If investor characteristics and search costs differ between standard and specialist segments, this should also be reflected in differences in the influence of other variables. For example, we expect inexperienced investors to be less fee-sensitive, as they are more reliant on financial advice that regularly is compensated for by higher load fees. This should result in fund growth being less negatively (or even positively) dependent on fees in standard segments than in specialist segments. Furthermore, SHILLER (1984) argues that investors are not able to correctly assess risk. This problem should be more severe with inexperienced investors. Therefore, investors in standard segments should be less sensitive to differences in funds' risk and fees.

To examine differences in the influence of past risk and fees on fund growth between standard and specialist segments, we add an interaction term between $\operatorname{std}_{\mathrm{i}, \mathrm{t}-1}$ and $\mathrm{D}$ as well as between Fees $_{\mathrm{i}, \mathrm{t}-1}$ and $\mathrm{D}$ in our regression model. Again, D takes on the value 1 if the fund belongs to a standard segment and zero otherwise:

$$
\begin{aligned}
g_{i, t}= & \beta_{1} \operatorname{Rank}_{i, t-1}+\beta_{2} \operatorname{Rank}_{i, t-1}^{2}+\beta_{1 L} \operatorname{Rank}_{i, t-1} D+\beta_{2 L} \operatorname{Rank}_{i, t-1}^{2} D \\
& \beta_{3} \text { Std }_{i, t-1}+\beta_{3 L} \operatorname{std}_{i, t-1} D+\beta_{4} \text { Fees }_{i, t-1}+\beta_{4 L} \text { Fees }_{i, t-1} D+\ldots
\end{aligned}
$$

Similar as above, the influence of the interacted terms denotes the additional influence of the respective variable if a fund belongs to a standard segment as compared to a specialist segment. This approach allows us to explicitly test for statistical differences in the influence of risk and fees between standard and specialist segments. Results are presented in Column (D) of Table 2.

Our result of a stronger convexity in standard segments remains unaffected by the inclusion of the two additional interaction terms. With respect to the influence of risk, we now find an interesting difference. Risk has a negative, but insignificant influence on fund growth in specialist segments. However, in standard segments there is a positive impact, as indicated by the positive influence of $\operatorname{std}_{\mathrm{i}, \mathrm{t}-1} \mathrm{D}$. Therefore, the stronger risk-taking incentives of fund managers in standard segments due to the more pronounced convexity of the PFR there as compared to specialist segments are even reinforced.

Looking at the influence of fees we also find a striking difference. Fees have a strong negative impact on fund growth in specialist segments. In standard segments, this negative influence is neutralized, as indicated by the significantly positive influence of $\mathrm{Fees}_{\mathrm{i}, \mathrm{t}-1} \mathrm{D}$, which is larger (in absolute terms) than the negative influence of Fees ${ }_{\mathrm{i}, \mathrm{t}-1} \mathrm{D}$. Investors in standard segments do not seem to be fee-averse. This is consistent with the view that many of them are reliant on professional advice, which is compensated for by high load fees. Furthermore, such inexperienced investors are more likely to be driven to funds that spend a lot of money on 
distribution and marketing. These funds usually charge higher load fees, too. In contrast, investors in specialist segments seem to be very fee-sensitive and strongly prefer low-fee funds.

To get a more detailed picture of the influence of fees on fund growth, we split up our fees variable, Fees ${ }_{i, t-1}$, into the load fees a fund levies, $\operatorname{Load}_{i, t-1}$, and the total expense ratio of the fund, $\mathrm{TER}_{\mathrm{i}, \mathrm{t}-1 .[10]}$ Both fee variables are interacted with the standard-segment dummy, D. Whereas expenses are usually levied to cover the cost of running the fund and compensating the fund manager, load fees are used to compensate brokers and to cover marketing expenditures. If our conjecture that investors in standard segments are more reliant on professional advice is true, then we should, on the one hand, see a stronger positive influence of load fees in these segments as compared to specialist segments. On the other hand, expenses directly hurt performance, as they are deducted from the asset base of the fund. Therefore, we expect a negative influence of the total expense ratio in standard as well as in specialist segments.

The results presented in Column (E) of Table 2 confirm our arguments. We find a significantly positive influence of load fees on fund growth in standard segments, but not in specialist segments. This might also be due to the fact, that these investors are usually wealthier and rely on fee-based advisors rather than brokers, that have to be compensated via loads.

In contrast, the influence of the total expense ratio is strongly negative in specialist as well as in standard segments. There is no systematic difference across segments, as indicated by the insignificant influence of $\mathrm{TER}_{\mathrm{i}, \mathrm{t}-1} \mathrm{D}$.

\subsection{Stability of Results}

In this section we examine the robustness of our results. We start by reporting results using an alternative methodology to capture the convexity of the PFR. Next, we report results from estimations, where we base segment ranks on different performance measures other than returns and take a look at the temporal stability of our results. Finally, we explore whether our results are driven by funds with specific individual characteristics.

\section{Piecewise Linear Regression Approach}

Instead of using squared ranks to account for the non-linearity of the PFR, we apply a piecewise linear regression approach. This methodology allows us to separately determine the sensitivity of growth to performance in each performance quintile. We follow SIRRI/TUFANO (1998) and group the $2^{\text {nd }}$ to $4^{\text {th }}$ quintile together.[11] Ranks are decomposed in the following way: the lowest quintile as $\mathrm{LOW}_{\mathrm{i}, \mathrm{t}-1}=\min \left(\operatorname{Rank}_{\mathrm{i}, \mathrm{t}-1} ; 0.2\right)$, the three middle quintiles as $\mathrm{MID}_{\mathrm{i}, \mathrm{t}-1}=\min \left(\operatorname{Rank}_{\mathrm{i}, \mathrm{t}-1^{-}}\right.$ $\left.\mathrm{LOW}_{\mathrm{i}, \mathrm{t}-1} ; 0.6\right)$, and the top quintile as $\mathrm{HIGH}_{\mathrm{i}, \mathrm{t}-1}=\mathrm{Rank}_{\mathrm{i}, \mathrm{t}-1}-\left(\mathrm{LOW}_{\mathrm{i}, \mathrm{t}-1}+\mathrm{MID}_{\mathrm{i}, \mathrm{t}-1}\right)$. The coefficients on these rank decomposition represent the slope of the PFR in the respective quintile(s). Our regression model then reads:

$$
\begin{aligned}
g_{i, t}= & \beta_{\text {low }} L O W_{i, t-1}+\beta_{\text {low }}^{L} L_{\text {LOW }} \text { i,t-1 } D+\beta_{\text {mid }} \text { MID }_{i, t-1}+\beta_{\text {mid }}^{L} M_{i, t-1} D \\
& +\beta_{\text {high }} H_{I G H} H_{i, t-1}+\beta_{\text {high }}^{L} H_{I G H} H_{i, t-1} D+\gamma \text { Controls }+\sum_{j=1993}^{2001} \alpha_{j} D_{j}+\varepsilon_{i, t}
\end{aligned}
$$


The estimation results of model (3) are presented in Table 3.

\section{Please insert Table 3}

All of our results remain qualitatively unchanged. Results from Column (A) confirm the strong convexity of the PFR in the whole sample. In Columns (B), (C) and (D) we observe a significant influence of $\mathrm{HIGH}_{\mathrm{i}, \mathrm{t}-1} \mathrm{D}$, but not of $\mathrm{LOW}_{\mathrm{i}, \mathrm{t}-1} \mathrm{D}$ and $\mathrm{MID}_{\mathrm{i}, \mathrm{t}-1} \mathrm{D}$. This indicates a stronger convexity of the PFR in standard than in specialist segments. Thereby, our results from Table 2 are confirmed. The difference in the convexity is driven by the much stronger performance sensitivity in the top-quintile. This is consistent with the argument that the additional convexity in standard segments is driven by a higher visibility of top-funds there than in specialist segments. Furthermore, our earlier results with respect to the differences in the influence of fees and risk are also confirmed (see Columns (C) and (D)).[12]

\section{Alternative Performance Measures}

In the examinations above we base our segment ranks on raw returns. As a stability check, we redo all regressions using segment ranks based on Sharpe-Ratios, FAMA/FRENCH (1993) 3-factor alphas and CARHART (1997) 4-factor alphas. We report results for the BARBER/ODEAN/ZHENG (2004) squared rank specification (1) in Table 4.

\section{Please insert Table 4}

We still find a convex PFR in the whole sample (Columns (A), (D), and (G)) and a more pronounced convexity in standard than in specialist segments (Columns (B)-(C), (E)-(F), (H)-(I)). Furthermore, our results with respect to the influence of risk and fees are not affected by the change of the performance measure (Columns $(\mathrm{C}),(\mathrm{F})$ and $(\mathrm{I})$ ). Furthermore, the $\mathrm{R}^{2}$ of the regressions based on risk-adjusted measures are never as high as those of the respective regressions using returns (see Table 2). This agrees to the findings of PATEL/ZECKHAUSER/HENDRICKS (1994). Results (not reported here) using the SIRRI/TUFANO (1998) piecewise-linear regression methodology and ranks based on the riskadjusted performance measures are very similar.

\section{Temporal Stability}

It is possible that the influence of the various determinants of fund growth changes over time. In Table 5 we present the estimation results from the extended version (with interaction terms for fees and risk) of model (1) for the three subperiods 1993-1995, 1996-1998, and 1999-2001. We report results for segment ranks based on returns.

\section{Please insert Table 5}

Our main result of a more convex PFR in standard segments is very stable over time. The influence of $\operatorname{Rank}_{i, t-1}^{2} \mathrm{D}$ is significantly positive in all subperiods. Furthermore, investors in specialist segments are never significantly less risk-averse than investors in standard segments. However, the results with respect to the influence of fees slightly differ between the subperiods. The influence of the expense ratio is usually negative except of in the period 1993-1995, where it is only significantly negative in standard segments. Regarding load fees, we find no significant 
influence in specialist segments in the later two subperiods, and a weakly negative influence in the first period. In standard segments, we find a significantly positive influence of loads as compared to the influence of loads in specialist segments in the first two subperiods, but not in the 1999-2001 period. In this period, the influence of loads in specialist segments is not significantly different from zero and the difference in the influence of loads between standard and specialist segments is insignificant, too.[13]

Results (not reported here) do not change if we base ranks on one of the risk-adjusted measures instead of returns. Our results are also very similar, if we use the piecewise-linear regression approach suggested by SIRRI/TUFANO (1998) instead of the squared rank specification.

\section{Influence of Individual Fund Characteristics}

Funds from standard segments are larger and older than funds from specialist segments. The median fund according to size in standard segments has a TNA of 275.25 million USD, while the median fund in specialist segments has a TNA of only 167.6 million USD. The median age of funds from standard as well as specialist segments is 6 years. However, the mean age is 11.31 years in standard segments, but only 8.43 years in specialist segments.

Therefore, if the convexity of the PFR for larger or older funds is greater than for smaller or younger funds, respectively, this could also drive our results. To examine this possibility, we interact the slope coefficients of model (1) not only with a dummy D indicating whether a fund belongs to a standard or specialist segment, but also with a dummy $\mathrm{D}_{\text {big }}$ and $\mathrm{D}_{\text {old }}$, respectively. $\mathrm{D}_{\text {big }}$ equals one, if a fund's size is above the median TNA and zero otherwise. Accordingly, $\mathrm{D}_{\text {old }}$ equals one, if a fund's age is above the median age and zero otherwise.[14] We estimate two models where we only include dummy-interactions with either the big-fund or the old-fund dummy, respectively, and one model where we include dummy interactions with the standardsegment dummy, the big-fund dummy and the old-fund dummy in one model. Estimation results of these extended models are presented in Table 6.

\section{Please insert Table 6}

Our results show that the convexity of the PFR is actually less pronounced for large (old) funds, as indicated by the significantly negative influence of $\operatorname{Rank}_{\mathrm{i}, \mathrm{t}-1} \mathrm{D}_{\text {big }}\left(\operatorname{Rank}_{\mathrm{i}, \mathrm{t}-1} \mathrm{D}_{\text {old }}\right)$ in Column (A) (Column (B)) and Column (C). This result also confirms the result of CHEVALIER/ELLISON (1997), who report a less convex PFR for older funds. Overall, our results show that the difference in age and size of funds from specialist and standard segments does not drive our result. In contrast, solely based on the differences in age and size, we would expect a stronger convexity of the PFR in specialist segments as compared to standard segments.

We also conduct the same examination using the piecewise-linear regression methodology described above. Results (not reported here) again indicate that the convexity of the PFR is less pronounced for older and larger funds. Similarly, we examine the influence of the load status on the convexity of the PFR. Our results (not reported) indicate, that the convexity of the PFR does not differ between load and no-load funds. 


\section{Conclusion}

This paper investigates how the PFR varies between different market segments of the equity mutual fund industry. Differences in search costs for funds and in investor wealth and investor characteristics between these segments can cause such differences. Our main result is that the convexity of the PFR is more pronounced in standard segments than in specialist segments. Furthermore, we find that load fees have a positive impact on fund growth in standard segments, but not in specialist segments. Finally, our results indicate that investors in standard segments buy relatively risky funds, whereas investors in specialist segments prefer funds with relatively low risk. Our main results are very stable over time as well as with respect to different methodological approaches. They are also robust against the influence of individual fund characteristics like age, size, and load status that might influence the convexity of the PFR.

Identifying differences in the convexity of the PFR has important implications for fund managers. A convex PFR leads to risk-taking incentives for fund managers [BROWN/HARLOW/STARKS (1996), KEMPF/RUENZI (2004a)]. The strength of these incentives positively depends on the convexity of the PFR. Therefore, our results indicate that risk-taking incentives for fund managers in standard segments are stronger than for managers in specialist segments. These stronger incentives are even reinforced by a positive influence of risk on fund growth in standard segments. Whether fund managers do actually engage more heavily in risk taking activities in standard segments than in specialist segments is an open empirical question left for future research. 
Table 1: Independent Variables in Empirical Study

\begin{tabular}{|c|c|c|}
\hline Variable & Description & Examined in \\
\hline $\operatorname{std}_{i, t}$ & $\begin{array}{l}\text { Monthly return standard } \\
\text { deviation of fund } i \text { in year } t\end{array}$ & e.g. SIRRI/TUFANO (1998) \\
\hline$g_{i, t-1}$ & $\begin{array}{l}\text { Growth of fund } \mathrm{i} \text { in the previous } \\
\text { year }\end{array}$ & $\begin{array}{l}\text { e.g. JAIN/WU (2000) and } \\
\text { KEMPF/RUENZI (2004c) }\end{array}$ \\
\hline $\operatorname{Age}_{i, t}$ & Age in years of fund $\mathrm{i}$ in year $\mathrm{t}$ & e.g. KEMPF/RUENZI (2004b) \\
\hline $\mathrm{TNA}_{\mathrm{i}, \mathrm{t}}$ & $\begin{array}{l}\text { Total net assets under } \\
\text { management in million USD of } \\
\text { fund i in year } t\end{array}$ & e.g. SIRRI/TUFANO (1998) \\
\hline $\operatorname{Load}_{\mathrm{i}, \mathrm{t}}$ & $\begin{array}{l}\text { Sum of all front and back-end } \\
\text { load fees of fund i in year t. }\end{array}$ & e.g. BARBER/ODEAN/ZHENG (2004) \\
\hline $\mathrm{TER}_{\mathrm{i}, \mathrm{t}}$ & $\begin{array}{l}\text { Total expense ratio of fund } i \text { in } \\
\text { year } t\end{array}$ & e.g. BARBER/ODEAN/ZHENG (2004) \\
\hline Fees $_{i, t}$ & $\begin{array}{l}1 / 7^{\text {th }} \text { of the total load fee plus } \\
\text { the TER of fund } i \text { in year } t\end{array}$ & e.g. SIRRI/TUFANO (1998) \\
\hline Turnover $_{i, t}$ & Turnover ratio of fund $\mathrm{i}$ in year $\mathrm{t}$ & $\begin{array}{l}\text { e.g. BERGSTRESSER/POTERBA } \\
(2002)\end{array}$ \\
\hline$g(\operatorname{Seg})_{i, t}$ & $\begin{array}{l}\text { Growth rate of fund i's segment } \\
\text { in year } t\end{array}$ & e.g. FANT/O’NEAL (2000) \\
\hline
\end{tabular}


Table 2: The Performance Flow Relationship

Period: 1993-2001

\begin{tabular}{|c|c|c|c|c|c|}
\hline & (A) & (B) & (C) & (D) & $(E)$ \\
\hline Rank $_{\mathrm{i}, \mathrm{t}-1}$ & -0.0673 & 0.0520 & 0.1250 & $0.1540^{* *}$ & $0.1233^{*}$ \\
\hline $\operatorname{Rank}_{\mathrm{i}, \mathrm{t}-1}^{2}$ & $0.6260^{* * *}$ & $0.4273^{\star * *}$ & $0.3348^{* * *}$ & $0.3411^{* * *}$ & $0.3660^{* * *}$ \\
\hline $\operatorname{Rank}_{\mathrm{i}, \mathrm{t}-1} \mathrm{D}$ & & $-0.1993^{* * *}$ & $-0.2819^{* *}$ & $-0.3818^{* * *}$ & $-0.3444^{* * *}$ \\
\hline $\operatorname{Rank}_{\mathrm{i}, \mathrm{t}-1}^{2} \mathrm{D}$ & & $0.3396^{\star * *}$ & $0.4468^{* * *}$ & $0.4938^{* * *}$ & $0.4621^{\text {***}}$ \\
\hline $\mathrm{std}_{\mathrm{i}, \mathrm{-1}}$ & -0.0523 & -0.0453 & -0.0338 & -0.0638 & -0.0427 \\
\hline $\operatorname{std}_{\mathrm{i},-1-1} \mathrm{D}$ & & & & $0.1729^{* * *}$ & $0.1688^{* * *}$ \\
\hline$g_{i, t-1}$ & $0.1449^{* * *}$ & $0.1453^{* * *}$ & $0.0235^{\star * *}$ & $0.1447^{* * *}$ & $0.1447^{\star * *}$ \\
\hline $\operatorname{lnTNA} A_{i, t-1}$ & $-0.0329^{* * *}$ & $-0.0330^{* * *}$ & $-0.0291^{* * *}$ & $-0.0335^{\star * *}$ & $-0.0359^{* * *}$ \\
\hline $\ln \mathrm{Age}_{\mathrm{i}, \mathrm{t}-1}$ & $-0.0437^{* * *}$ & $-0.0435^{\star * *}$ & $-0.0665^{\star}$ & $-0.0439^{* * *}$ & $-0.0522^{* * *}$ \\
\hline Fees $_{i, t-1}$ & -0.7572 & -0.6006 & 0.0738 & $-1.6194^{* *}$ & \\
\hline Fees $_{i, t-1} D$ & & & & $1.8728^{* *}$ & \\
\hline Load $_{\mathrm{i}, \mathrm{t}-1}$ & & & & & 0.0017 \\
\hline $\operatorname{Load}_{\mathrm{i}, \mathrm{t}-1} \mathrm{D}$ & & & & & $0.0093^{* * *}$ \\
\hline $\mathrm{TER}_{\mathrm{i}, \mathrm{t}-1}$ & & & & & $-3.4849^{* * *}$ \\
\hline $\mathrm{TER}_{\mathrm{i}, \mathrm{t}-1} \mathrm{D}$ & & & & & 0.2067 \\
\hline Turnover $_{i,-1}$ & $0.0146^{* *}$ & $0.0148^{* *}$ & $0.0143^{*}$ & $0.0145^{\star \star}$ & $0.0162^{* * *}$ \\
\hline$g(\text { Seg })_{i t-1}$ & $0.2873^{* * *}$ & $0.2851^{* * *}$ & $0.5743^{* * *}$ & $0.2845^{\star * *}$ & $0.2852^{* * *}$ \\
\hline$g(\operatorname{Seg})^{2}{ }_{i, t-1}$ & $-0.0463^{* * *}$ & $-0.0457^{* * *}$ & $-0.0391^{* * *}$ & $-0.0456^{\star * *}$ & $-0.0457^{* * *}$ \\
\hline $\mathrm{N}$ & 15,348 & 15,348 & 6,681 & 15,348 & 15,348 \\
\hline $\mathrm{R}^{2}$ & $19.46 \%$ & $19.63 \%$ & $17.46 \%$ & $19.71 \%$ & $19,84 \%$ \\
\hline
\end{tabular}

Column (A) shows regression results from model (1) as described in the main text, where we leave aside the interaction terms. Column (B) contains results from an estimation of the fully specified model. Column (C) contains results from a regression where all share classes of a fund are aggregated into the largest share class. In Column (D) an interaction term between a standardsegment dummy, D, and fees and risk, respectively, is added. In Column (E) the fee measure is split up in load fees, Load $_{\mathrm{i}, \mathrm{t}-1}$, and the expense ratio, $\mathrm{TER}_{\mathrm{i}, \mathrm{t}-1}$. Both measures are also interacted with a large-segment dummy. The next to last row contains the number of observations. The $\mathrm{R}^{2}$ of the regressions is shown in the last row. ${ }^{* * *},{ }^{* *}$, and ${ }^{*}$ denotes statistical significance at the $1 \%, 5 \%$ and $10 \%$-level, respectively. The shaded areas denote the coefficients indicating differences in the shape of the performance flow relationship and in the influence of fees and past return risk. 
Table 3: The PFR estimated using piecewise-linear regressions

Period: 1993-2001

\begin{tabular}{|c|c|c|c|c|}
\hline & (A) & (B) & (C) & (D) \\
\hline $\mathrm{LOW}_{\mathrm{i},-\mathrm{t}-1}$ & $0.3086^{* * *}$ & $0.3138^{* * *}$ & $0.4242^{\star * *}$ & $0.3672^{* * *}$ \\
\hline $\mathrm{MID}_{\mathrm{i}, \mathrm{t}-1}$ & $0.4148^{* * *}$ & $0.4337^{* * *}$ & $0.4265^{\star * *}$ & $0.4291^{* * *}$ \\
\hline $\mathrm{HIGH}_{\mathrm{i}, \mathrm{t}-1}$ & $1.9879^{* * *}$ & $1.1398^{* * *}$ & $1.1505^{\star * *}$ & $1.1441^{* * *}$ \\
\hline $\mathrm{LOW}_{\mathrm{i}, \mathrm{t}-1} \mathrm{D}$ & & -0.0096 & -0.2181 & -0.1355 \\
\hline $\mathrm{MID}_{\mathrm{i}, \mathrm{t}-1} \mathrm{D}$ & & -0.0286 & -0.0137 & -0.0241 \\
\hline $\mathrm{HIGH}_{\mathrm{i}, \mathrm{t}-1} \mathrm{D}$ & & $1.4347^{* \star *}$ & $1.4095^{\star * *}$ & $1.4393^{* * *}$ \\
\hline $\operatorname{std}_{i, t-1}$ & -0.0506 & -0.0425 & -0.0629 & -0.0412 \\
\hline $\operatorname{std}_{\mathrm{i}, \mathrm{t}-1} \mathrm{D}$ & & & $0.1731^{* * *}$ & $0.1678^{* * *}$ \\
\hline$g_{i, t-1}$ & $0.1432^{* * *}$ & $0.1438^{* * *}$ & $0.1433^{* * *}$ & $0.1432^{* * *}$ \\
\hline $\operatorname{lnTNA} A_{i, t-1}$ & $-0.0328^{* * *}$ & $-0.0331^{* * *}$ & $-0.0335^{\star * *}$ & $-0.0360^{* * *}$ \\
\hline $\ln A_{g} e_{i, t-1}$ & $-0.0439^{* \star *}$ & $-0.0436^{* * *}$ & $-0.0440^{* * *}$ & $-0.0527^{\star \star *}$ \\
\hline Fees $_{i, t-1}$ & -0.7300 & -0.6376 & $-1.3905^{\star}$ & \\
\hline Fees $_{\mathrm{i}, \mathrm{t}-1} \mathrm{D}$ & & & $1.3430^{*}$ & \\
\hline $\operatorname{Load}_{\mathrm{i}, \mathrm{t}-1}$ & & & & 0.0021 \\
\hline $\operatorname{Load}_{i, t-1} \mathrm{D}$ & & & & $0.0090^{* *}$ \\
\hline $\mathrm{TER}_{\mathrm{i}, \mathrm{t}-1}$ & & & & $-3.2022^{* * *}$ \\
\hline $\mathrm{TER}_{\mathrm{i}, \mathrm{t}-1} \mathrm{D}$ & & & & -1.0708 \\
\hline Turnover $_{i, t-1}$ & $0.0146^{* *}$ & $0.0144^{* *}$ & $0.0141^{* *}$ & $0.0158^{* * *}$ \\
\hline$g(\text { Seg })_{i, t-1}$ & $0.2863^{* * *}$ & $0.2836^{\star * *}$ & $0.2834^{* * *}$ & $0.2840^{* * *}$ \\
\hline$g(\text { Seg })^{2}{ }_{i, t-1}$ & $-0.0459^{* * *}$ & $-0.0451^{* * *}$ & $-0.0452^{* * *}$ & $-0.0453^{* * *}$ \\
\hline $\mathrm{R}^{2}$ & $19.80 \%$ & $20.09 \%$ & $20.15 \%$ & $20.29 \%$ \\
\hline
\end{tabular}

This table shows regression results from model (3) as described in the main text. In Columns $(B)$ and $(C)$ the performance variables are interacted with a dummy $D$ for standard segments. In Column (C) the lagged standard deviation and fee burden are also interacted with this dummy. In Column (D) the fee measure is split up in load fees, $\operatorname{Load}_{\mathrm{i}, \mathrm{t}-1}$, and the expense ratio, $\mathrm{TER}_{\mathrm{i}, \mathrm{t}-1}$. Both measures are also interacted with a largesegment dummy. The number of observations in all regressions is 15,348 . The $R^{2}$ of the regressions is shown in the last row. ${ }^{* * *},{ }^{* *}$, and ${ }^{*}$ denotes statistical significance at the $1 \%, 5 \%$ and $10 \%$-level, respectively. The shaded areas denote the coefficients indicating differences in the shape of the performance flow relationship and in the influence of fees and past return risk. 
Table 4: Ranks based on Sharpe-Ratios, Three- and Four-Factor Alphas

Period: 1993-2001

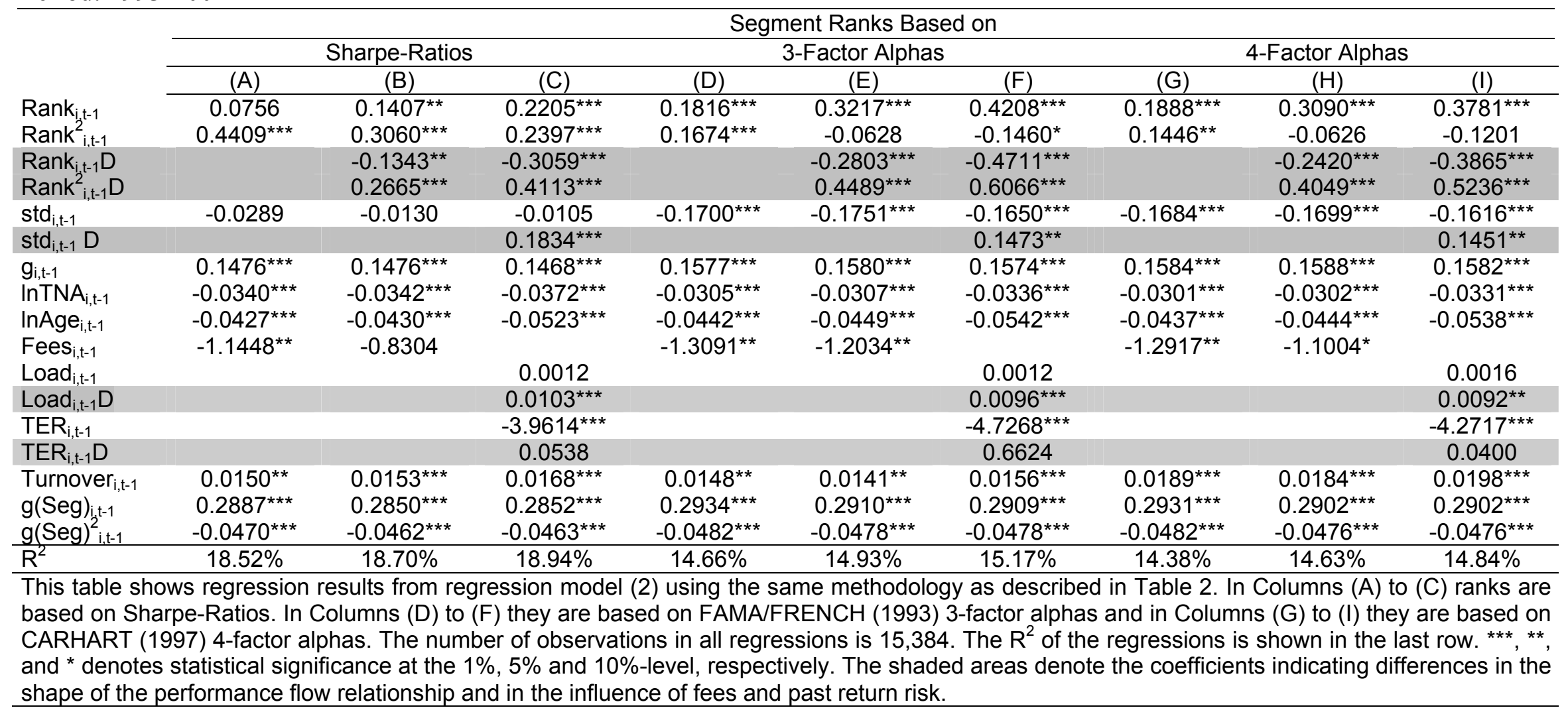


Table 5: Temporal Stability of Results

\begin{tabular}{|c|c|c|c|}
\hline & \multicolumn{3}{|c|}{ Segment Ranks Based on Return Ranks } \\
\hline & 1993-1995 & 1996-1998 & 1999-2001 \\
\hline Rank $_{\mathrm{i}, \mathrm{t}-1}$ & 0.3436 & -0.0472 & $0.1970^{\star \star}$ \\
\hline $\operatorname{Rank}_{\mathrm{i}, \mathrm{t}-1}^{2}$ & 0.0147 & $0.4561^{* * *}$ & $0.3394^{* * *}$ \\
\hline $\operatorname{Rank}_{\mathrm{i}, \mathrm{t}-1} \mathrm{D}$ & $-0.5113^{*}$ & $-0.3399^{* *}$ & $-0.3748^{* * *}$ \\
\hline $\operatorname{Rank}_{i, t-1}^{2} D$ & $0.8246^{* *}$ & $0.6095^{\star * *}$ & $0.4005^{\star * *}$ \\
\hline $\operatorname{std}_{\mathrm{i},-1}$ & -0.3339 & $-0.3253^{* *}$ & -0.0095 \\
\hline $\operatorname{std}_{i, t-1} D$ & 0.0512 & 0.0171 & $0.2114^{* \star *}$ \\
\hline $\operatorname{Load}_{i, t-1}$ & $-0.0175^{*}$ & 0.0003 & 0.0056 \\
\hline $\operatorname{Load}_{i, t-1} \mathrm{D}$ & $0.0270^{* *}$ & $0.0152^{* *}$ & 0.0049 \\
\hline $\mathrm{TER}_{\mathrm{i}, \mathrm{t}-1}$ & 2.2620 & $-3.4517^{*}$ & $-5.4310^{* * *}$ \\
\hline $\mathrm{TER}_{\mathrm{i}, \mathrm{t}-1} \mathrm{D}$ & $-10.2228^{* *}$ & -1.4789 & 1.7282 \\
\hline & $\ldots$ & & \\
\hline $\mathrm{N}$ & 1,471 & 4.100 & 9,777 \\
\hline $\mathrm{R}^{2}$ & $24.62 \%$ & $24.77 \%$ & $17.43 \%$ \\
\hline
\end{tabular}

This table shows regression results from the same model as in Column (E) of Table 2 for different time periods. Segment ranks are based on returns. The next to last row contains the number of observations and the $R^{2}$ of the regressions is shown in the last row. ${ }^{* * *},{ }^{* *}$, and ${ }^{*}$ denotes statistical significance at the $1 \%, 5 \%$ and $10 \%$-level, respectively. The shaded areas denote the coefficients indicating differences in the shape of the performance flow relationship and in the influence of fees and past return risk. Dots represent the other control variables not reported in this table. They are the same as in Tables 2-4.

Table 6: Influence of Other Fund Characteristics

\begin{tabular}{|c|c|c|c|}
\hline & \multicolumn{3}{|c|}{ Segment Ranks Based on Return Ranks } \\
\hline & (A): Large vs. Small & (B): Old vs. Young & (C): Complete Model \\
\hline Rank $_{\mathrm{i}, \mathrm{t}-1}$ & $-0.7664^{* * *}$ & -0.1584 & $-0.6061^{* * *}$ \\
\hline $\operatorname{Rank}_{\mathrm{i}, \mathrm{t}-1}^{2}$ & $1.0108^{* * *}$ & $0.8477^{* * *}$ & $0.8935^{\star \star * *}$ \\
\hline $\operatorname{Rank}_{\mathrm{i}, \mathrm{t}-1} \mathrm{D}_{\text {big }}$ & $1.5959^{* * *}$ & & $1.5031^{\star \star *}$ \\
\hline $\operatorname{Rank}^{2}{ }^{2},-1-1 D_{b i g}$ & $-0.9887^{* * *}$ & & $-0.8528^{* * *}$ \\
\hline Rank $_{\mathrm{i}, \mathrm{t}-1} \mathrm{D}_{\text {old }}$ & & $0.2425^{\star}$ & 0.1903 \\
\hline $\operatorname{Rank}^{2}{ }_{i, t-1} D_{\text {old }}$ & & $-0.4498^{* * *}$ & $-0.4621^{* * *}$ \\
\hline $\begin{array}{l}\operatorname{Rank}_{\mathrm{i}, \mathrm{t}-1} \mathrm{D} \\
\operatorname{Rank}_{\mathrm{i}, \mathrm{t}-1} \mathrm{D}\end{array}$ & & & $\begin{array}{c}-0.3236^{* * *} \\
0.4312^{* * *}\end{array}$ \\
\hline$\frac{\cdots}{R^{2}}$ & $\begin{array}{c}\ldots \\
20.81 \%\end{array}$ & $15.96 \%$ & $21.25 \%$ \\
\hline
\end{tabular}

This table shows regression results from an extension of model (2) from the main text. Performance coefficients are interacted with dummies indicating whether the fund's age is above the median age (dummy-interaction $D_{\text {old }}$ ), whether the fund's size is above the median size (dummy-interaction $D_{\text {big }}$ ) or whether the fund is in a standard segment (dummy-interaction D), respectively, or not. Segment ranks are based on returns. All share classes are aggregated. The number of observations in all regressions is 6,681 . The $R^{2}$ of the regressions is shown in the last row. ${ }^{* *},{ }^{* *}$, and ${ }^{*}$ denotes statistical significance at the $1 \%, 5 \%$ and $10 \%$-level, respectively. Dots represent the other independent variables not reported in this table. They are the same as in Tables 2-4. 


\section{FOOTNOTES}

[1] Although there are also a lot of complicated bonus packages based on, e.g., average three-year performance, the main part of fund managers' salary is usually related to assets under management [KHORANA (1996)].

[2] This is often the case, as many families offer their investors the possibility to switch between its funds for free.

[3] Evidence along similar lines is presented by SAWICKI (2000) and (2001), DELGUERCIO/TKAC (2002) and KAPLAN/SCHOAR (2003). They examine the PFR in the Australian wholesale mutual fund market, the pension fund market and the private equity fund market, respectively. These markets are dominated by professional investors. The PFR in those markets is less convex than in the retail mutual fund market. These papers argue that the less convex PFR they find can be explained by professional investors being better-informed and less prone to behavioral biases than their retail counterparts. However, there is also some interesting experimental evidence indicating that professional traders are not less prone to behavioral biases than lay people [see, e.g., GLASER/LANGER/WEBER (2003)].

[4] SIRRI/TUFANO (1998) apply FAMA/MACBETH (1973) regressions instead of pooled regressions to examine the PFR. We repeat our analysis using FAMA/MACBETH (1973) regressions, too, and obtain very similar results to those using the pooled regression approach.

[5] All results not reported here for the sake of brevity are available from the author on request.

[6] We assume, that investors mainly care about previous year performance. Our results (not reported in tables) are very similar, if we use the performance over the past three years instead of just the last year.

[7] Source: CRSP ${ }^{\mathrm{TM}}$, Center for Research in Security Prices. Graduate School of Business, The University of Chicago. Used with permission. All rights reserved. crsp.uchicago.edu. Further information on the CRSP database is available in CARHART (1997).

[8] Instead of excluding observations with extreme growth rates, we also winsorize them or use a growth rate of $1000 \%$ percent as cutoff. Our main results do not change.

[9] In principle, it would also be interesting to examine the influence of tracking error in order to gain a better understanding of the reaction of fund investors to active risk. However, as the calculation of active risk requires the definition of a benchmark for each fund and it is very hard to define an appropriate benchmark index even at the segment level, we refrain from such an examination.

[10] The loads investors actually pay are often lower than the loads officially reported in the CRSP database. For example, brokers often offer discounts to their clients. Nevertheless, the maximum load reported in the database is still the best proxy for the actual load burden and is regularly used in the literature [e.g., BARBER/ODEAN/ZHENG (2004)].

[11] We also apply the piecewise linear regression approach using different slope coefficients for all five quintiles. Our main results are not affected.

[12] Results are very similar if we include a Top-10, Top-5 or Top-3 fund dummy as described above.

[13] However, looking at the (not reported) results for separate estimations for subsamples of funds from specialist and standard segments, we find a significantly positive influence of loads in the latter, but not in the first.

[14] For these stability test we aggregate all classes of a fund into the first class and use the median of the aggregate TNAs of all classes to define our dummy. The age of a fund is given by the age of its oldest share class. Results are very similar if we do not aggregate, but treat each fund class as individual observation. Results also do not change if we use means instead of medians to define our dummies. 


\section{REFERENCES}

BARBER, B.M., T. ODEAN and L. ZHENG (2004): "Out of Sight, Out of Mind: The Effects of Expenses on Mutual Fund Flows", Journal of Business, forthcoming.

BERGSTRESSER, D. and J. POTERBA (2002): "Do After-Tax Returns Affect Mutual Fund Inflows?", Journal of Financial Economics 63, pp. 381-414.

BOLLEN, N.P.B. and J.A. BUSSE (2001): "On the Timing Ability of Mutual Fund Managers", Journal of Finance 56, pp. 1075-1094.

BROWN, S.J. and W.N. GOETZMANN (1995): "Performance Persistence", Journal of Finance 50, pp. 679-698.

BROWN, K.C., W. HARLOW and L.T. STARKS (1996): "Of Tournaments and Temptations: An Analysis of Managerial Incentives in the Mutual Fund Industry", Journal of Finance 51, pp. 85-110.

CARHART, M. (1997): “On Persistence in Mutual Fund Performance”, Journal of Finance 52, pp. 57-82.

CHEVALIER, J. and G. ELLISON (1997): "Risk Taking by Mutual Funds as Response to Incentives", Journal of Political Economy 105, pp. 1167-1200.

DELGUERCIO, D. and P. TKAC (2002): "The Determinants of the Flows of Funds of Managed Portfolios: Mutual Funds vs. Pension Funds", Journal of Financial and Quantitative Analysis 37, pp. 523-58.

ELTON, E.J., M.J. GRUBER and C.R. BLAKE (1996): "The Persistence of Risk-Adjusted Mutual Fund Performance", Journal of Business 69, pp. 133-157.

ELTON, E.J., M.J. GRUBER and C.R. BLAKE (2000): "Incentive Fees and Mutual Funds", Journal of Finance 58, pp. 779-804.

FAMA, E.F. and K.R. FRENCH (1993): "Common Risk Factors in the Return on Bonds and Stocks", Journal of Financial Economics 33, pp. 3-53.

FAMA, E.F. and J. MACBETH (1973): "Risk, Return, and Equilibrium: Empirical Tests", Journal of Political Economy 81, pp. 607-36.

FANT, L.F. and E.S. O’NEAL (2000): “Temporal Changes in the Determinants of Mutual Fund Flows", Journal of Financial Research 23, pp. 353-71.

GLASER, M., T. LANGER and M. WEBER (2003): „On the Trend Recognition and Forecasting Ability of Professional Traders", CEPR Working Paper No. 3904.

GOETZMANN, W. and N. PELES (1997): “Cognitive Dissonance and Mutual Fund Investors", Journal of Financial Research 20, pp. 145-58. 
HUANG, J., K.D. WEI and H. YAN (2004): „Participation Costs and the Sensitivity of Fund Flows to Past Performance“, Working Paper.

IPPOLITO, R.A. (1992): “Consumer Reaction to Measures of Poor Quality: Evidence from the Mutual Fund Industry", Journal of Law and Economics 35, pp. 45-70.

JAIN, C.J. and J.S. WU (2000): "Truth in Mutual Fund Advertising: Evidence on Future Performance and Fund Flows", Journal of Finance 55, pp. 937-58.

KAPLAN, S. and SCHOAR, A. (2003): "Private Equity Performance: Returns, Persistence and Capital Flows", Working Paper.

KEMPF, A. and S. RUENZI (2004a): "Tournaments in Mutual Fund Families“, Working Paper.

KEMPF, A. and S. RUENZI (2004b): "Family Matters: The Performance Flow Relationship in the Mutual Fund Industry“", Working Paper.

KEMPF, A. and S. RUENZI (2004c): "Die Qual der Wahl: Eine empirische Untersuchung zum Status-Quo Bias im Fondsmarkt", in: M. Bank and B. Schiller (eds.): Finanzintermediation Theoretische, wirtschaftspolitische und praktische Aspekte aktueller Entwicklungen im Bankund Börsenwesen, Stuttgart: Schäffer-Poeschel, pp. 103-22.

KHORANA, A. (1996): “Top Management Turnover: An Empirical Investigation of Mutual Fund Managers", Journal of Financial Economics 40, pp. 403-27.

PATEL, J., R.J. ZECKHAUSER and D. HENDRICKS (1994): „Investment Flows and Performance: Evidence from Mutual Funds, Cross-Border Investments, and New Issues", in: R. Sato, R.M. Levich and R.V. Ramachandran (eds.): Japan, Europe and International Financial Markets: Analytical and Empirical Perspectives, Cambridge: Cambridge University Press, pp. 51-72.

SAWICKI, J. (2000): "Investors' Response to the Performance of Professional Fund Managers: Evidence from the Australian Funds Wholesale Market", Australian Journal of Management 25, pp. 47-67.

SAWICKI, J. (2001): “Investors' Differential Response to Managed Fund Performance”, Journal of Financial Research 24, pp. 367-84.

SHEFRIN, H. and M. STATMAN (1985): "The Disposition to Sell Winners Too Early and Ride Losers Too Long: Theory and Evidence", Journal of Finance 40, pp. 777-90.

SHILLER, R.J. (1984): "Stock Prices and Social Dynamics", Brookings Papers on Economic Activity 2, pp. 457-510.

SIRRI, E. and P. TUFANO (1998): "Costly Search and Mutual Fund Flows", Journal of Finance, pp. 1589-1622. 
CfR working papers are available for download from www.cfr-cologne.de.

Hardcopies can be ordered from: centre for financial Research ( $C F R$ ), albertus magnus platz, 50923 koeln, Germany.

2011

No. Author(s) Title

11-16 V. Agarwal, J.-P. Gómez, Management Compensation and Market Timing under Portfolio R. Priestley Constraints

11-15 T. Dimpfl, S. Jank Can Internet Search Queries Help to Predict Stock Market Volatility?

11-14 P. Gomber, U. Schweikert, Liquidity Dynamics in an Electronic Open Limit Order Book:

E. Theissen

An Event Study Approach

11-13 D. Hess, S. Orbe

Irrationality or Efficiency of Macroeconomic Survey Forecasts? Implications from the Anchoring Bias Test

11-12 D. Hess, P. Immenkötter

Optimal Leverage, its Benefits, and the Business Cycle

11-11 N. Heinrichs, D. Hess,

C. Homburg, M. Lorenz,

S. Sievers

11-10 A. Kempf, O. Korn,

S. Saßning

Extended Dividend, Cash Flow and Residual Income Valuation Models - Accounting for Deviations from Ideal Conditions

Portfolio Optimization using Forward - Looking Information

11-08 G. Cici, L.-F. Palacios

11-07 V. Agarwal, G. D. Gay, Window Dressing in Mutual Funds

11-06 N. Hautsch, D. Hess,

D. Veredas

11-05 G. Cici

11-04 S. Jank

11-03 G.Fellner, E.Theissen

Determinants and Implications of Fee Changes in the Hedge Fund Industry

On the Use of Options by Mutual Funds: Do They Know What They Are Doing?

The Impact of Macroeconomic News on Quote Adjustments, Noise, and Informational Volatility

The Prevalence of the Disposition Effect in Mutual Funds' Trades

Mutual Fund Flows, Expected Returns and the Real Economy

Short Sale Constraints, Divergence of Opinion and Asset Value: Evidence from the Laboratory

11-02 S.Jank

Are There Disadvantaged Clienteles in Mutual Funds?

The Role of Hedge Funds as Primary Lenders 
No. Author(s) Title

10-20 G. Cici, S. Gibson, Missing the Marks? Dispersion in Corporate Bond Valuations J.J. Merrick Jr. Across Mutual Funds

10-19 J. Hengelbrock,

Market Response to Investor Sentiment

E. Theissen, C. Westheide

$10-18$

G. Cici, S. Gibson

The Performance of Corporate-Bond Mutual Funds:

Evidence Based on Security-Level Holdings

10-17 D. Hess, D. Kreutzmann,

O. Pucker

Projected Earnings Accuracy and the Profitability of Stock

Recommendations

10-16 S. Jank, M. Wedow

10-15 G. Cici, A. Kempf, A. Puetz

Sturm und Drang in Money Market Funds: When Money Market Funds Cease to Be Narrow

Caught in the Act:

How Hedge Funds Manipulate their Equity Positions

10-14 J. Grammig, S. Jank

Creative Destruction and Asset Prices

10-13 S. Jank, M. Wedow

Purchase and Redemption Decisions of Mutual Fund Investors and the Role of Fund Families

10-12 S. Artmann, P. Finter,

The Cross-Section of German Stock Returns:

A. Kempf, S. Koch,

E. Theissen

New Data and New Evidence

M. Chesney, A. Kempf

The Value of Tradeability

10-10 S. Frey, P. Herbst

10-09 V. Agarwal, W. Jiang, Y. Tang, B. Yang

The Influence of Buy-side Analysts on Mutual Fund Trading

Uncovering Hedge Fund Skill from the Portfolio Holdings They Hide

10-08 V. Agarwal, V. Fos, W. Jiang

Inferring Reporting Biases in Hedge Fund Databases from Hedge Fund Equity Holdings

10-07 V. Agarwal, G. Bakshi, J. Huij

Do Higher-Moment Equity Risks Explain Hedge Fund Returns?

10-06 J. Grammig, F. J. Peter

Tell-Tale Tails

10-05 K. Drachter, A. Kempf

10-04 J. Fang, A. Kempf M. Trapp

10-03 P. Finter, A. NiessenRuenzi, S. Ruenzi

10-02 D. Hunter, E. Kandel, S. Kandel, R. Wermers

Höhe, Struktur und Determinanten der ManagervergütungEine Analyse der Fondsbranche in Deutschland

Fund Manager Allocation

The Impact of Investor Sentiment on the German Stock Market

Endogenous Benchmarks

10-01 S. Artmann, P. Finter, A. Kempf

Determinants of Expected Stock Returns: Large Sample Evidence from the German Market

No. Author(s) Title

09-17 E. Theissen




\begin{tabular}{|c|c|c|}
\hline $09-16$ & M. Trapp & $\begin{array}{l}\text { Trading the Bond-CDS Basis - The Role of Credit Risk } \\
\text { and Liquidity }\end{array}$ \\
\hline $09-15$ & $\begin{array}{l}\text { A. Betzer, J. Gider, } \\
\text { D.Metzger, E. Theissen }\end{array}$ & Strategic Trading and Trade Reporting by Corporate Insiders \\
\hline $09-14$ & $\begin{array}{l}\text { A. Kempf, O. Korn, } \\
\text { M. Uhrig-Homburg }\end{array}$ & The Term Structure of Illiquidity Premia \\
\hline $09-13$ & W. Bühler, M. Trapp & $\begin{array}{l}\text { Time-Varying Credit Risk and Liquidity Premia in Bond and } \\
\text { CDS Markets }\end{array}$ \\
\hline $09-12$ & W. Bühler, M. Trapp & $\begin{array}{l}\text { Explaining the Bond-CDS Basis - The Role of Credit Risk and } \\
\text { Liquidity }\end{array}$ \\
\hline $09-11$ & $\begin{array}{l}\text { S. J. Taylor, P. K. Yadav, } \\
\text { Y. Zhang }\end{array}$ & Cross-sectional analysis of risk-neutral skewness \\
\hline $09-10$ & $\begin{array}{l}\text { A. Kempf, C. Merkle, } \\
\text { A. Niessen }\end{array}$ & $\begin{array}{l}\text { Low Risk and High Return - How Emotions Shape } \\
\text { Expectations on the Stock Market }\end{array}$ \\
\hline 09-09 & $\begin{array}{l}\text { V. Fotak, V. Raman, } \\
\text { P. K. Yadav }\end{array}$ & Naked Short Selling: The Emperor`s New Clothes? \\
\hline 09-08 & $\begin{array}{l}\text { F. Bardong, S.M. Bartram, } \\
\text { P.K. Yadav }\end{array}$ & $\begin{array}{l}\text { Informed Trading, Information Asymmetry and Pricing of } \\
\text { Information Risk: Empirical Evidence from the NYSE }\end{array}$ \\
\hline 09-07 & $\begin{array}{l}\text { S. J. Taylor , P. K. Yadav, } \\
\text { Y. Zhang }\end{array}$ & $\begin{array}{l}\text { The information content of implied volatilities and model-free } \\
\text { volatility expectations: Evidence from options written on } \\
\text { individual stocks }\end{array}$ \\
\hline 09-06 & S. Frey, P. Sandas & The Impact of Iceberg Orders in Limit Order Books \\
\hline 09-05 & $\begin{array}{l}\text { H. Beltran-Lopez, P. Giot, } \\
\text { J. Grammig }\end{array}$ & Commonalities in the Order Book \\
\hline 09-04 & J. Fang, S. Ruenzi & $\begin{array}{l}\text { Rapid Trading bei deutschen Aktienfonds: } \\
\text { Evidenz aus einer großen deutschen Fondsgesellschaft }\end{array}$ \\
\hline 09-03 & $\begin{array}{l}\text { A. Banegas, B. Gillen, } \\
\text { A. Timmermann, } \\
\text { R. Wermers }\end{array}$ & The Performance of European Equity Mutual Funds \\
\hline 09-02 & $\begin{array}{l}\text { J. Grammig, A. Schrimpf, } \\
\text { M. Schuppli }\end{array}$ & $\begin{array}{l}\text { Long-Horizon Consumption Risk and the Cross-Section } \\
\text { of Returns: New Tests and International Evidence }\end{array}$ \\
\hline 09-01 & O. Korn, P. Koziol & The Term Structure of Currency Hedge Ratios \\
\hline
\end{tabular}

2008

\begin{tabular}{|c|c|c|}
\hline No. & Author(s) & Title \\
\hline $08-12$ & $\begin{array}{l}\text { U. Bonenkamp, } \\
\text { C. Homburg, A. Kempf }\end{array}$ & Fundamental Information in Technical Trading Strategies \\
\hline $08-11$ & O. Korn & Risk Management with Default-risky Forwards \\
\hline $08-10$ & J. Grammig, F.J. Peter & $\begin{array}{l}\text { International Price Discovery in the Presence } \\
\text { of Market Microstructure Effects }\end{array}$ \\
\hline 08-09 & C. M. Kuhnen, A. Niessen & Public Opinion and Executive Compensation \\
\hline 08-08 & A. Pütz, S. Ruenzi & $\begin{array}{l}\text { Overconfidence among Professional Investors: Evidence from } \\
\text { Mutual Fund Managers }\end{array}$ \\
\hline 08-07 & P. Osthoff & What matters to SRI investors? \\
\hline 08-06 & A. Betzer, E. Theissen & $\begin{array}{l}\text { Sooner Or Later: Delays in Trade Reporting by Corporate } \\
\text { Insiders }\end{array}$ \\
\hline
\end{tabular}


08-05

08-04

N. Hautsch, D. Hess,

C. Müller

08-03

D. Hess, H. Huang,

A. Niessen

08-02 R. Chakrabarti, W. Megginson, P. Yadav

08-01 C. Andres, E. Theissen
Determinanten der Aktionärspräsenz auf Hauptversammlungen deutscher Aktiengesellschaften

Price Adjustment to News with Uncertain Precision

How Do Commodity Futures Respond to Macroeconomic News?

Corporate Governance in India

Setting a Fox to Keep the Geese - Does the Comply-or-Explain Principle Work?

2007

No. Author(s)

07-16 M. Bär, A. Niessen, S. Ruenzi

07-15 A. Niessen, S. Ruenzi

07-14 O. Korn

07-13 A. Kempf, P. Osthoff

07-12 J. Grammig, E. Theissen, O. Wuensche

07-11 V. Agarwal, J. R. Kale

07-10 M. Kasch-Haroutounian, E. Theissen

07-09 V. Agarwal, N. D. Daniel, N. Y. Naik

07-08 N. C. Brown, K. D. Wei, R. Wermers

07-07 A. Betzer, E. Theissen

07-06 V. Agarwal, L. Wang

07-05 J. Grammig, A. Schrimpf

07-04 V. Agarwal, N.M. Boyson, N.Y. Naik

07-03 D. Hess, A. Niessen

07-02 A. Kempf, S. Ruenzi, T. Thiele

07-01 M. Hagemeister, A. Kempf
Title

The Impact of Work Group Diversity on Performance:

Large Sample Evidence from the Mutual Fund Industry

Political Connectedness and Firm Performance:

Evidence From Germany

Hedging Price Risk when Payment Dates are Uncertain

SRI Funds: Nomen est Omen

Time and Price Impact of a Trade: A Structural Approach

On the Relative Performance of Multi-Strategy and Funds of Hedge Funds

Competition Between Exchanges: Euronext versus Xetra

Do hedge funds manage their reported returns?

Analyst Recommendations, Mutual Fund Herding, and Overreaction in Stock Prices

Insider Trading and Corporate Governance:

The Case of Germany

Transaction Costs and Value Premium

Asset Pricing with a Reference Level of Consumption:

New Evidence from the Cross-Section of Stock Returns

Hedge Funds for retail investors?

An examination of hedged mutual funds

The Early News Catches the Attention:

On the Relative Price Impact of Similar Economic Indicators

Employment Risk, Compensation Incentives and Managerial Risk Taking - Evidence from the Mutual Fund Industry -

CAPM und erwartete Renditen: Eine Untersuchung auf Basis der Erwartung von Marktteilnehmern 
No.

Author(s) Title

06-13 S. Čeljo-Hörhager,

A. Niessen

06-12 R. Wermers, Y. Wu, J. Zechner

06-11 U. v. Lilienfeld-Toal,

S. Ruenzi

06-10

A. Kempf, P. Osthoff

06-09 R. Wermers, T. Yao J. Zhao

06-08 M. Hoffmann, B. Kempa

06-07 K. Drachter, A. Kempf, M. Wagner

06-06 J.P. Krahnen, F.A. Schmid, E. Theissen

06-05 S. Ber, S. Ruenzi

06-04 A. Kempf, D. Mayston

06-03 O. Korn, C. Koziol

06-02 O. Scaillet, L. Barras, R. Wermers

06-01 A. Niessen, S. Ruenzi
How do Self-fulfilling Prophecies affect Financial Ratings? - An experimental study

Portfolio Performance, Discount Dynamics, and the Turnover of Closed-End Fund Managers

Why Managers Hold Shares of Their Firm: An Empirical Analysis

The Effect of Socially Responsible Investing on Portfolio Performance

The Investment Value of Mutual Fund Portfolio Disclosure

The Poole Analysis in the New Open Economy

Macroeconomic Framework

Decision Processes in German Mutual Fund Companies:

Evidence from a Telephone Survey

Investment Performance and Market Share: A Study of the German Mutual Fund Industry

On the Usability of Synthetic Measures of Mutual Fund NetFlows

Liquidity Commonality Beyond Best Prices

Bond Portfolio Optimization: A Risk-Return Approach

False Discoveries in Mutual Fund Performance: Measuring Luck in Estimated Alphas

Sex Matters: Gender Differences in a Professional Setting

No. Author(s) Title

05-16 E. Theissen

05-15

$05-14$

R. Kosowski,

A. Timmermann,

R. Wermers, H. White

05-13 D. Avramov, R. Wermers

05-12 K. Griese, A. Kempf

05-11 S. Ber, A. Kempf,

S. Ruenzi

05-10 M. Bär, A. Kempf,

S. Ruenzi

05-09 M. Hoffmann

05-08 S. Ruenzi
An Analysis of Private Investors' Stock Market Return Forecasts

Does Anonymity Matter in Electronic Limit Order Markets

Can Mutual Fund "Stars“ Really Pick Stocks?

New Evidence from a Bootstrap Analysis

Investing in Mutual Funds when Returns are Predictable

Liquiditätsdynamik am deutschen Aktienmarkt

Determinanten der Mittelzuflüsse bei deutschen Aktienfonds

Is a Team Different From the Sum of Its Parts?

Evidence from Mutual Fund Managers

Saving, Investment and the Net Foreign Asset Position

Mutual Fund Growth in Standard and Specialist Market Segments 
05-05 H. Beltran, J. Grammig, A.J. Menkveld

05-04 M. Hoffmann

05-03 M. Hoffmann

05-02 A. Kempf, C. Memmel

05-01 S. Frey, J. Grammig
Status Quo Bias and the Number of Alternatives - An Empirical Illustration from the Mutual Fund Industry

Is Best Really Better? Internalization of Orders in an Open Limit Order Book

Understanding the Limit Order Book: Conditioning on Trade Informativeness

Compensating Wages under different Exchange rate Regimes

Fixed versus Flexible Exchange Rates: Evidence from Developing Countries

On the Estimation of the Global Minimum Variance Portfolio

Liquidity supply and adverse selection in a pure limit order book market

2004

No.

04-10 Author(s)

N. Hautsch, D. Hess

04-09 A. Kempf, K. Kreuzberg

04-08 N.F. Carline, S.C. Linn, P.K. Yadav

04-07 J.J. Merrick, Jr., N.Y. Naik P.K. Yadav

04-06 N.Y. Naik, P.K. Yadav

04-05 A. Kempf, S. Ruenzi

04-04 V. Agarwal, N.D. Daniel, N.Y. Naik

04-03 V. Agarwal, W.H. Fung, J.C. Loon, N.Y. Naik

04-02 A. Kempf, S. Ruenzi

04-01 I. Chowdhury, M. Hoffmann, A. Schabert
Title

Bayesian Learning in Financial Markets - Testing for the Relevance of Information Precision in Price Discovery

Portfolio Disclosure, Portfolio Selection and Mutual Fund Performance Evaluation

Operating performance changes associated with corporate mergers and the role of corporate governance

Strategic Trading Behaviour and Price Distortion in a Manipulated Market: Anatomy of a Squeeze

Trading Costs of Public Investors with Obligatory and Voluntary Market-Making: Evidence from Market Reforms

Family Matters: Rankings Within Fund Families and Fund Inflows

Role of Managerial Incentives and Discretion in Hedge Fund Performance

Risk and Return in Convertible Arbitrage:

Evidence from the Convertible Bond Market

Tournaments in Mutual Fund Families

Inflation Dynamics and the Cost Channel of Monetary

Transmission 
